\title{
RECIPROCAL EXCHANGE NETWORKS: IMPLICATIONS FOR MACROECONOMIC STABILITY
}

James Stodder (stodder@rh.edu), Rensselaer at Hartford, Hartford CT, 06120 (August 2000)

An earlier version of this paper was presented at the International Electronic and Electrical Engineering (IEEE) Engineering Management Society (EMS) Conference, in Albuquerque, New Mexico, August 2000.

Abstract: "Barter rings" in the US and Switzerland do billions of dollars of trade each year. Their turnover is seen to be counter-cyclical. Most studies of the internet's macroeconomic impact focus on the stabilizing effect of greater price and inventory flexibility. The pre-internet experience of these systems, however, suggests that, for networks independent of direct monetary exchange, expanded credit availability may be even more stabilizing.

\section{Introduction}

Faster and cheaper information on the internet means greater macroeconomic stability. That, at least, is a well-publicized view of internet-based commerce. By making it possible for purchasing firms and households to compare prices more widely, ecommerce has forced better price flexibility and greater resistance to inflation (Greenspan, 1999). Better supply tracking and demand estimation also helps keeps inventories lean, thus tamping down unplanned inventories (Wenninger 1999), an important precursor of recession.

But this literature on price and inventory flexibility has ignored another way that better information can be macro-stabilizing. As any loan-officer or central banker can attest, the prudent allocation of credit is both knowledge-intensive and highly uncertain. What if, instead of trying to estimate the proper amount of money and credit to complete all transactions, the balancing of all supplies and demands were known and calculated, through a central clearing house? The problem of how much money-stuff to create would disappear; money, in the conventional sense, would no longer exist.

Such moneyless exchange took place in the ancient storehouse economies (Polanyi 1947), and in the simplified models of microeconomic exchange -- both under conditions where the relevant information is centralized. The ancient storehouses economies collapsed, and monetary systems (from a root meaning 'to monitor') evolved because the information required to coordinate a complex economy was far too great to be centralized (Stodder 1995).

The internet is once again making large-scale information-centralization efficient, and centralized barter is an emerging form of e-commerce. Barter clearing-houses are growing with internet startups like swap.com, BarterTrust.com, and uBarter.com (Anders 2000).

The possible implications of moneyless business are not straightforward, nor without controversy. A few prominent economists have speculated that computer-networked 
barter might eventually replace our decentralized money -- as well as its centralized protector, central banking. Such questions have recently been asked by leading macroeconomists like Mervyn King, Deputy Governor of the Bank of England (King 1999, Beattie 1999), and Benjamin Friedman of Harvard (1999).

Friedman's view that central banking may be seriously challenged was a lead topic at a recent World Bank conference on the "Future of Monetary Policy and Banking" (World Bank 2000). His warnings have even sparked a pair of skeptical reviews in the Economist Magazine of London (2000a, 2000b). But no one, as far as I know, has looked at the direct evidence on this issue, the large-scale barter networks in existence for decades.

\section{Statement of the Argument}

If barter is informationally-centralized - on a network where, via a central resource, all parties can scan each other's bids and offers - it will tend to be counter-cyclical. The central records of such barter, possibly on computers, will track the bids (unmet demands) and offers (excess supplies) of all agents on the network. This is far more knowledge than is available to any "central" bank -- the knowledge it has to set the money-supply basis of exchange. Its broad monetary aggregates sit atop the decentralized "real" data in which investors and central bankers are interested. To get at this information, the bank can only scan indirect monetary indicators -- ratings of creditworthiness, and statistical leading indicators.

This is not to imply that a centralized barter administration cannot make mistakes, cannot extend too much or too little credit. Credit "inflation" was indeed evident in the early history of the world's largest barter exchange, the "Economic Ring" (Wirtschaftsring, or WIR) of Switzerland (Defila 1994, Stutz 1994). Such a centralized barter exchange, however, will have a better knowledge base on which to extend credit than any central bank.

The WIR was inspired by the ideas of an early 20th-century economist, Silvio Gesell (Defila 1994). Yet only one contemporary economist, to my knowledge, has examined the macroeconomic record of the WIR. Studer (1998) finds positive correlation between WIR credits advanced and the Swiss money supply, M1. This suggests that WIR follows a counter-cyclical credit "policy," one parallel to the monetary policy of the Swiss central bank. The data used in Studer's study, however, go back only to 1994.

This paper examines the historic data on two large barter exchanges -- the WIR, founded in 1930s Switzerland, and the International Reciprocal Trade Association (IRTA), founded in the US in the early 1970s. The data will show that the economic activity of both exchanges is counter-cyclical, rising and falling against, rather than with, the business cycle.

\section{The Data}

Because the financial record of these exchanges is not widely known, I provide the basic data. The North American data are available online (IRTA 1999). In the regressions to follow, I have only used the series up to 1995 , as the website states that the more recent years are extrapolations. 
Table 1: Volume of Corporate Barter,

\section{North American Companies, 1974-1995}

(in Millions of Current US Dollars)

$\begin{array}{cccc}\text { Year } & \text { Volume } & \text { Year } & \text { Volume } \\ \mathbf{1 9 7 4} & \$ 850 & \mathbf{1 9 8 6} & \$ 3200 \\ \mathbf{1 9 7 6} & 980 & \mathbf{1 9 8 7} & 3470 \\ \mathbf{1 9 7 7} & 1130 & \mathbf{1 9 8 8} & 3750 \\ \mathbf{1 9 7 8} & 1300 & \mathbf{1 9 8 9} & 4050 \\ \mathbf{1 9 7 9} & 1500 & \mathbf{1 9 9 0} & 4550 \\ \mathbf{1 9 8 0} & 1720 & \mathbf{1 9 9 1} & 5100 \\ \mathbf{1 9 8 1} & 1980 & \mathbf{1 9 9 2} & 5570 \\ \mathbf{1 9 8 2} & 2200 & \mathbf{1 9 9 3} & 6050 \\ \mathbf{1 9 8 3} & 2440 & \mathbf{1 9 9 4} & 6560 \\ \mathbf{1 9 8 4} & 2680 & \mathbf{1 9 9 5} & 7216 \\ \mathbf{1 9 8 5} & 2900 & & \end{array}$

Source: Barter by North American Companies, (http://ww2.dgsys.com/ irta/statisti.html).

Note that data for 1975 are missing, and in the present study, are interpolated. For the regressions, these nominal figures were adjusted by a 1992-based deflator for services, as explained in the text.

These IRTA data are evidently not of the highest quality. Table 1 shows clear roundingoff, and should therefore be considered only a first-order approximation. Whatever biases may have colored the compilation of this data, however, the desire to show a counter-cyclical tendency was apparently not one of them. I know of no empirical studies of the IRTA, apart from my own (Stodder 1998), that claim to find such macroeconomic stabilization. Paradoxically, this is a source of some confidence.

Note that high-quality data on total barter transactions carried out though the IRTA do exist, but are not in the public domain. All commercial barter credits count as regular income and must be filed on Form 1099-B of the US Internal Revenue Service (IRTA, 1995). Since the IRTA Corporate Trade Council (CTC) for these years showed no Canadian or Mexican companies, it is reasonable to conclude that most of the "North American" barter is US.

Although the US has more complete public economic statistics than almost any other country, the Swiss banking tradition is famous for the quality of its private records. The $\mathrm{WIR}$, organized as a bank, is no exception, giving three time-series to the US one. 
Table 2: Barter Turnover, Number of Firms, and Credit-on-Turnover, WIR-Bank, 1948-99 (in Millions of Current Swiss Franks)

\begin{tabular}{|c|c|c|c|c|c|c|c|}
\hline Year & Turnover & Participants & Credit & Year & Turnover & Participants & Credit \\
\hline 1948 & 1.1 & 814 & 0.3 & 1974 & 200.0 & 20902 & 73.0 \\
\hline 1949 & 2.0 & 1070 & 0.5 & 1975 & 204.7 & 21869 & 78.9 \\
\hline 1950 & 3.8 & 1574 & 1.0 & 1976 & 223.0 & 23172 & 82.2 \\
\hline 1951 & 6.8 & 2089 & 1.3 & 1977 & 233.2 & 23929 & 84.5 \\
\hline 1952 & 12.6 & 2941 & 3.1 & 1978 & 240.4 & 24479 & 86.5 \\
\hline 1953 & 20.2 & 4540 & 4.6 & 1979 & 247.5 & 24191 & 89.0 \\
\hline 1954 & 30.0 & 5957 & 7.2 & 1980 & 255.3 & 24227 & 94.1 \\
\hline 1955 & 39.1 & 7231 & 10.5 & 1981 & 275.2 & 24501 & 103.3 \\
\hline 1956 & 47.2 & 9060 & 11.8 & 1982 & 330.0 & 26040 & 127.7 \\
\hline 1957 & 48.4 & 10286 & 12.1 & 1983 & 432.3 & 28418 & 159.6 \\
\hline 1958 & 53.0 & 11606 & 13.1 & 1984 & 523.0 & 31330 & 200.9 \\
\hline 1959 & 60.0 & 12192 & 14.0 & 1985 & 673.0 & 34353 & 242.7 \\
\hline 1960 & 67.4 & 12567 & 15.4 & 1986 & 826.0 & 38012 & 292.5 \\
\hline 1961 & 69.3 & 12445 & 16.7 & 1987 & 1065.0 & 42227 & 359.3 \\
\hline 1962 & 76.7 & 12720 & 19.3 & 1988 & 1329.0 & 46895 & 437.3 \\
\hline 1963 & 83.6 & 12670 & 21.6 & 1989 & 1553.0 & 51349 & 525.7 \\
\hline 1964 & 101.6 & 13680 & 24.3 & 1990 & 1788.0 & 56309 & 612.5 \\
\hline 1965 & 111.9 & 14367 & 25.5 & 1991 & 2047.0 & 62958 & 731.7 \\
\hline 1966 & 121.5 & 15076 & 27.0 & 1992 & 2404.0 & 70465 & 829.8 \\
\hline 1967 & 135.2 & 15964 & 37.3 & 1993 & 2521.0 & 76618 & 892.3 \\
\hline 1968 & 152.2 & 17069 & 44.9 & 1994 & 2509.0 & 79766 & 904.1 \\
\hline 1969 & 170.1 & 17906 & 50.3 & 1995 & 2355.0 & 81516 & 890.6 \\
\hline 1970 & 183.3 & 18239 & 57.2 & 1996 & 2262.0 & 82558 & 869.8 \\
\hline 1971 & 195.1 & 19038 & 66.2 & 1997 & 2085.0 & 82793 & 843.6 \\
\hline 1972 & 209.3 & 19523 & 69.3 & 1998 & 1976.0 & 82751 & 807.7 \\
\hline 1973 & 196.7 & 20402 & 69.9 & 1999 & 1833.0 & 82487 & 788.7 \\
\hline
\end{tabular}

Sources: Data to 1983 are from Meierhofer (1984). Subsequent years are from Annual Reports and WIR, public relations department (2000). 


\section{The Regression Results}

\section{United States}

Figures 1 and 2 below give visual evidence of Corporate Barter's "mirror image" or negative correlation with US GDP, and its more positive correlation with Wholesale Inventories.

To deflate the nominal IRTA data of Table 1, the 1992 chained price index for Services was used. By most accounts US corporate barter is heavily weighted toward services (Healey 1996), especially in media and advertising. Gross Domestic Product is in real terms, using a 1992 chained deflator, from the Economic Report of the President (1996).

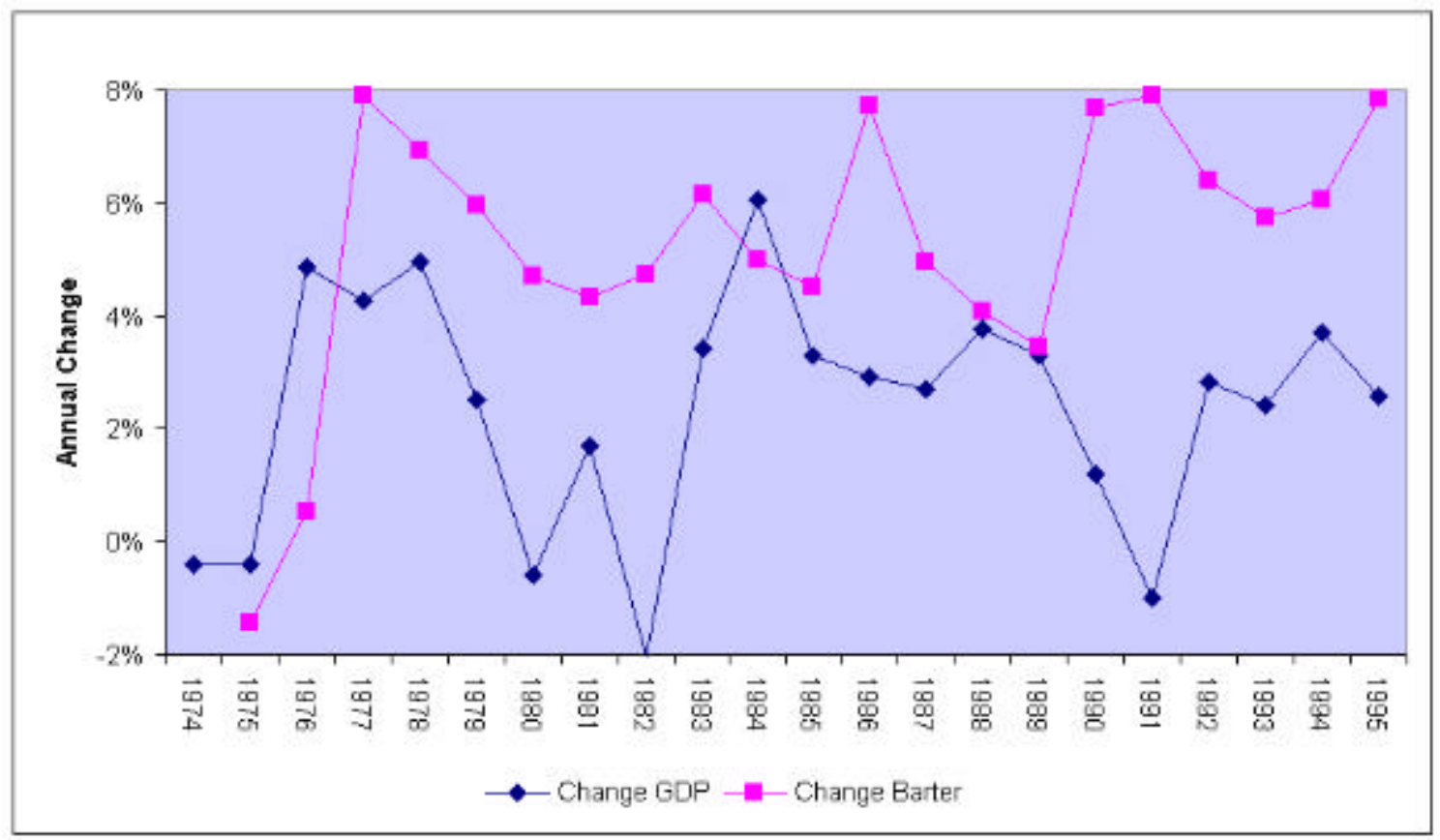

Figure 1: Annual Change in US GDP and Corporate Barter (1992 Prices), 1974-95. 


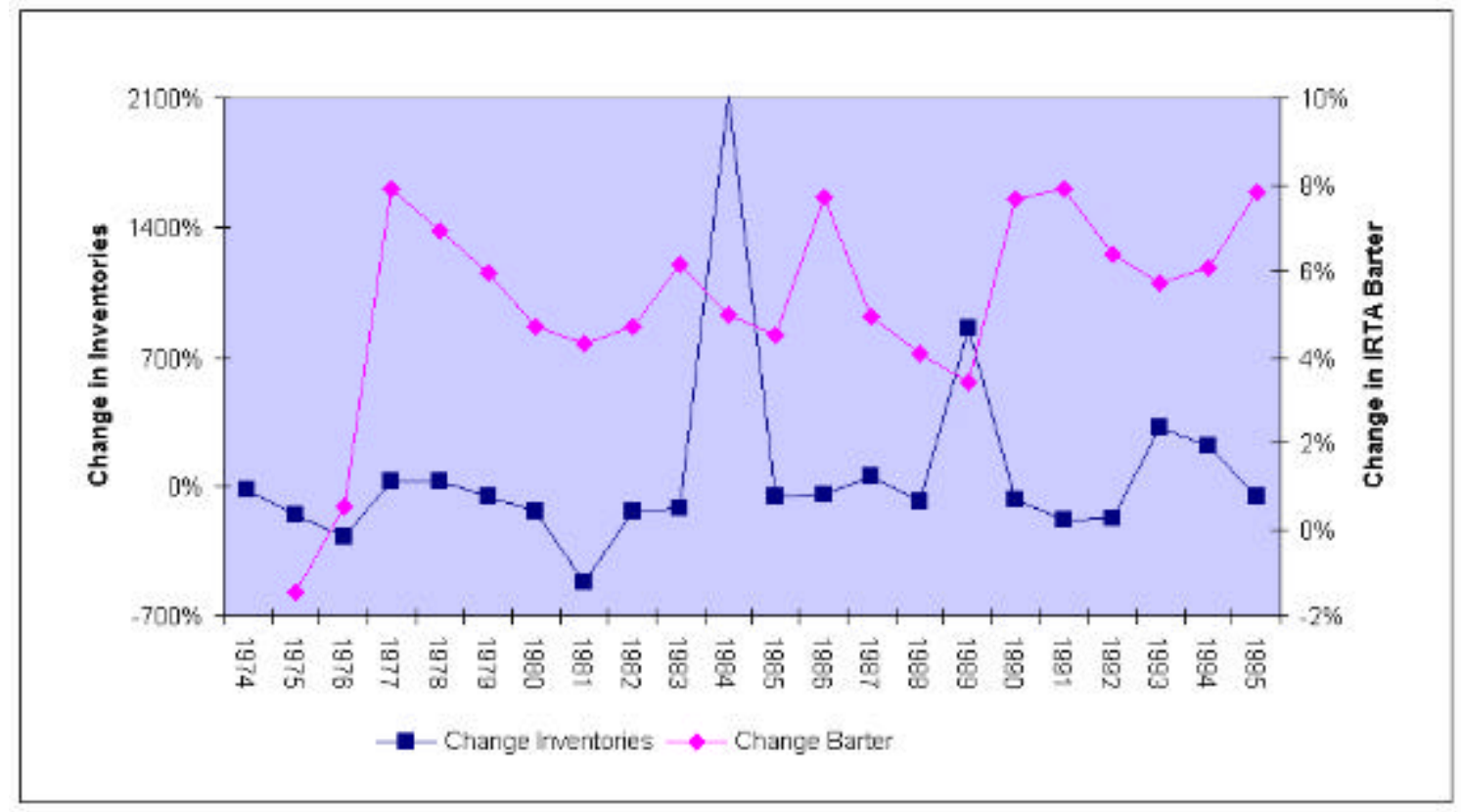

Figure 2: Annual Change in US Wholesale Inventories (left axis) and Corporate Barter (right axis) 1992 Prices, 1974-95.

Right-hand-side variables (in Table 3) are a Time trend, Wholesale Inventories, the percentage of Unemployment, and the Gross Domestic Product of the US economy. There is clear multicollinearity between these last two, as demonstrated by the Rsquared term being virtually unchanged when either one of them is dropped, in the last three estimates. Inventories show less multicollinearity, going "both ways" in the business cycle -- rising with expected upturns, but also with unexpected downturns. As a result of this independence, the coefficient on Inventories is significant throughout.

Estimates in Table 3 are first-order auto-regressive (AR1). Durbin Watson statistics fall mostly into the indeterminate area, so the null hypothesis of no auto-correlation can be rejected at level 5 percent. Regression [4] shows positive auto-correlation.

The coefficient on each variable is significant in at least one equation. All coefficients have signs consistent with the hypothesis of barter being counter-cyclical.

Table 3: US IRTA Corporate Barter, as Explained by Macroeconomic Variables

Dependent Variable: Corporate Barter, 1974-1995

$\left(\right.$ t-stats in italics, $*: p$-value $\left.<0.05,{ }^{o}: p<0.10\right)$

$\underline{\text { Equation }} \quad[1] \quad[2] \quad[3] \quad[4]$

Variable

Constant

$\begin{array}{rrrr}\mathbf{1 4 0 7 . 7 3} & \mathbf{- 3 4 4 . 3 7} & \mathbf{2 1 7 4 . 8 6} & \mathbf{1 0 7 0 . 1 1 0} \\ & & & \\ 0.641 & -0.446 & 3.496^{*} & 2.363\end{array}$




$\begin{array}{lrrrr}\text { Time } & \mathbf{1 3 2 . 1 1 8} & \mathbf{7 1 . 8 3 5} & \mathbf{1 5 9 . 4 9 1} & \mathbf{1 3 1 . 7 8 2} \\ & 1.659 & 1.977^{\circ} & 6.120^{*} & 5.099^{*} \\ \text { Wholesale Inv. } & \mathbf{1 5 . 6 3 5} & \mathbf{1 7 . 6 5 6} & \mathbf{1 4 . 1 3 5} & \mathbf{8 . 8 6 9} \\ & 2.801^{*} & 3.512^{*} & 3.825^{*} & 2.719^{*} \\ \text { Unemploy. } & \mathbf{- 0 . 3 4 2} & \mathbf{5 5 . 0 3 4} & & \\ & -0.851 & 2.172^{*} & & \\ \text { GDP } & \mathbf{1 8 . 2 7 9} & & \mathbf{- 0 . 4 6 8} & \\ & 0.365 & & -2.345^{*} & \\ \text { Regress. Mthd } & A R 1 & A R 1 & A R 1 & A R 1 \\ \text { R-squared } & 0.892 & 0.893 & 0.890 & 0.861 \\ \text { Adj. R-squared } & 0.867 & 0.875 & 0.871 & 0.846 \\ \text { Durbin-Watson } & 1.323 & 1.271 & 1.305 & 0.824 \\ \text { Rho } & 0.929 & 0.927 & 0.929 & 0.927 \\ \text { t-stat. of Rho } & 14.788^{*} & 14.706 * & 15.166^{*} & 15.014 * \\ \text { Log likelihood } & -124.14 & -124.60 & -124.22 & -127.16 \\ \text { Observations } & 22 & 22 & 22 & 22\end{array}$

Sources: IRTA (1995a) and Economic Report of the President (1996). Also, see Stodder (1998).

\section{Switzerland}

As Figure 3 below shows, growth in the number of WIR Participants has tracked Swiss Unemployment very closely, consistently maintaining a rate of about one-tenth the increase in the number of unemployed. Indeed, in the following regressions, the Unemployment term is the only one with strongly significant coefficients. The importance of Unemployment to WIR's Participant trend probably reflects its exclusion of "large" businesses, as established in the bank's rules since 1973 (Defila 1994). Employees in smaller firms are generally more subject to unemployment risks. Note that only 40 observations were available in these regressions, since the OECD data on Inventories only go back to 1960 . 


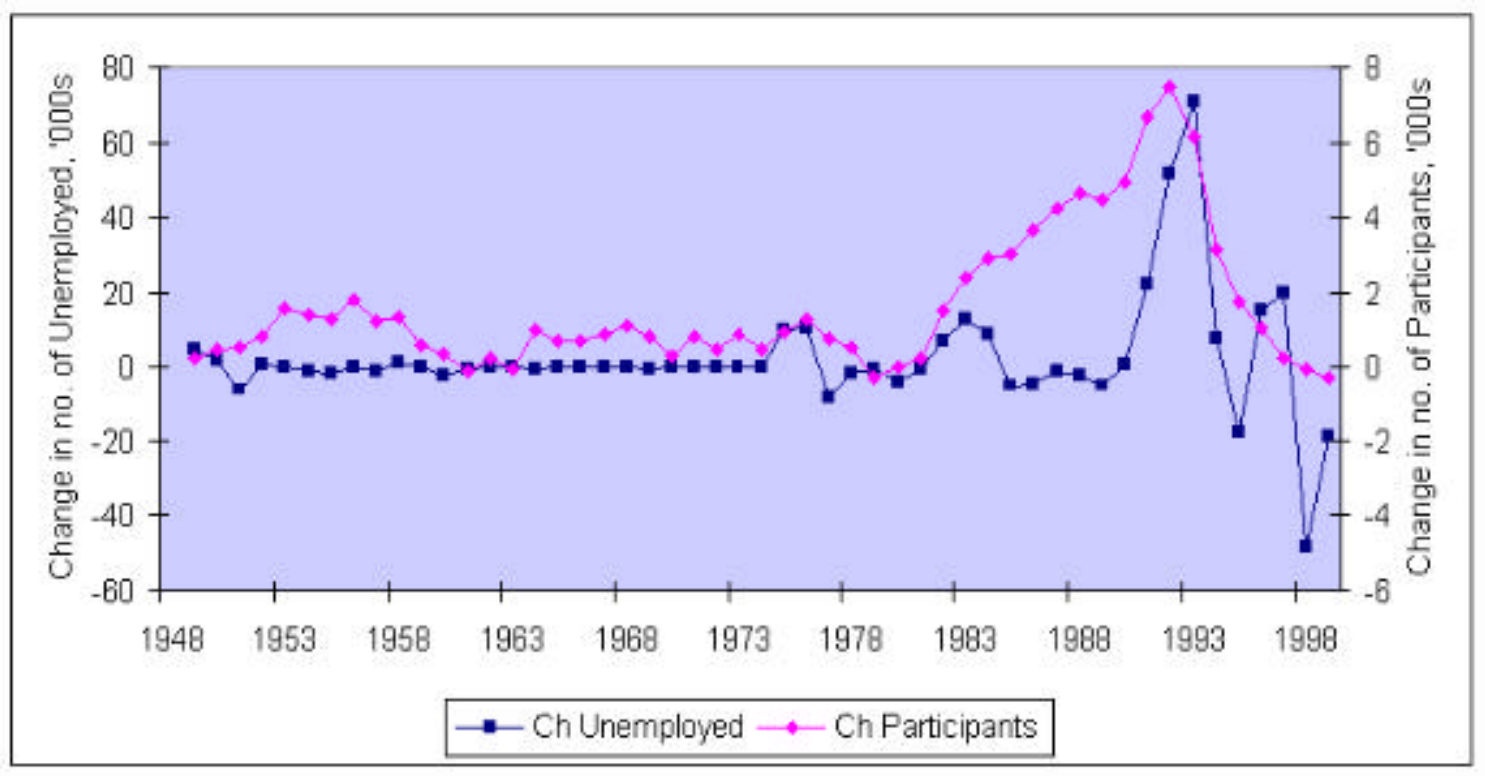

Figure 3: Change in number of Swiss Unemployed (in 1000s, left axis) and in number of WIR Participant-Accounts (in 1000s, right axis), 1948-99.

To deflate the WIR data, a chained price deflator on 1990 GDP is used. In Table 4 the dependent variable is the change in number of Participants. Right-hand-side variables are the Change in Unemployment, Change in Gross Domestic Product, and Change in all Private Inventories -- all in actual and not in percentage terms. The Durbin-Watson statistics show the hypothesis of no positive correlation cannot be rejected at 5 percent.

Turnover is seen to be largely pro-cyclical, rising and falling in tandem with the change in GDP and against changes in Inventories (See Figures 4 and 6). Credit advanced by the WIR, on the other hand, is highly counter-cyclical, correlated against GDP and with Inventories (See Figures 5 and 7).

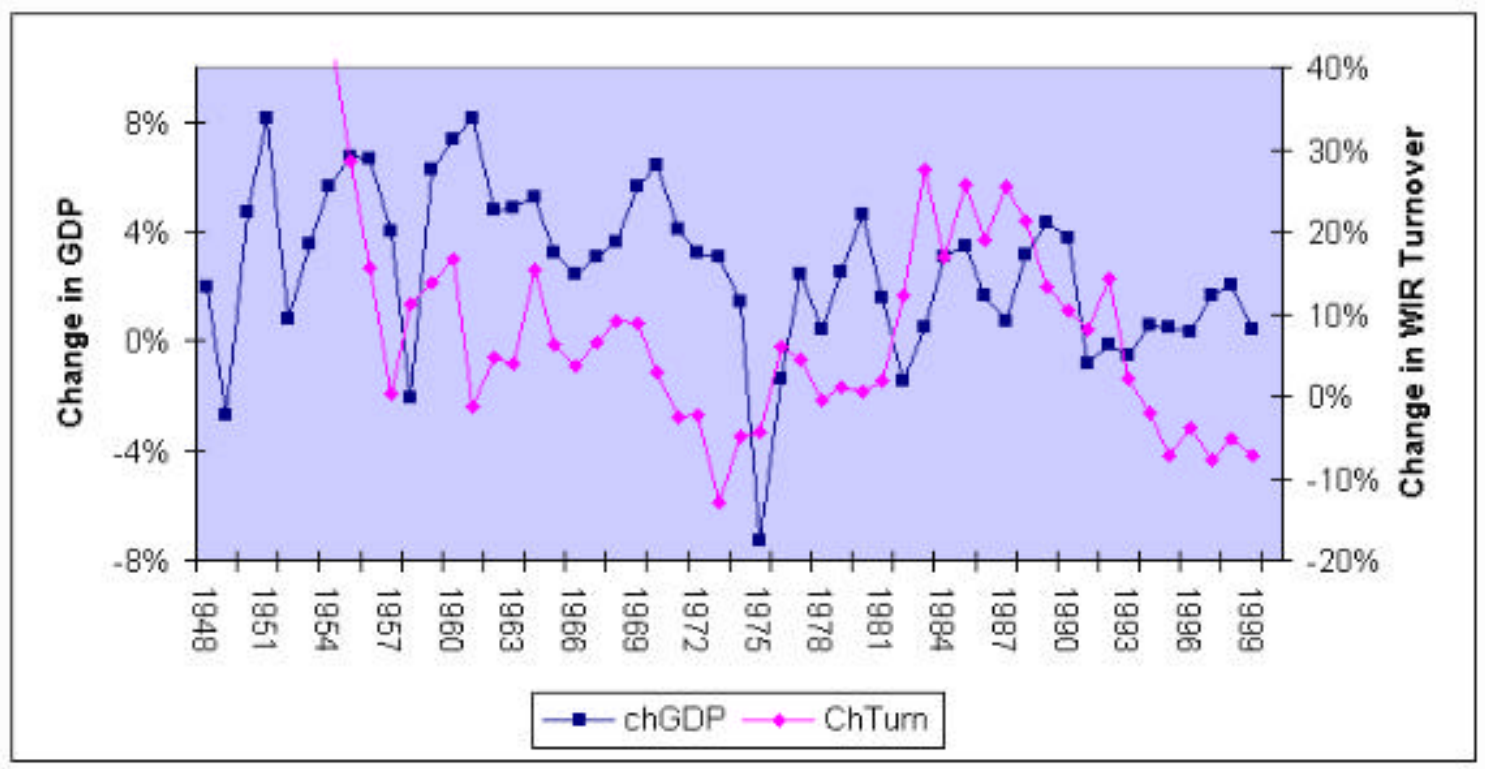


Figure 4: Change in Swiss GDP (left axis), and Change in Total WIR Turnover (right axis), both in 1990 Swiss Franks, 1948-99.

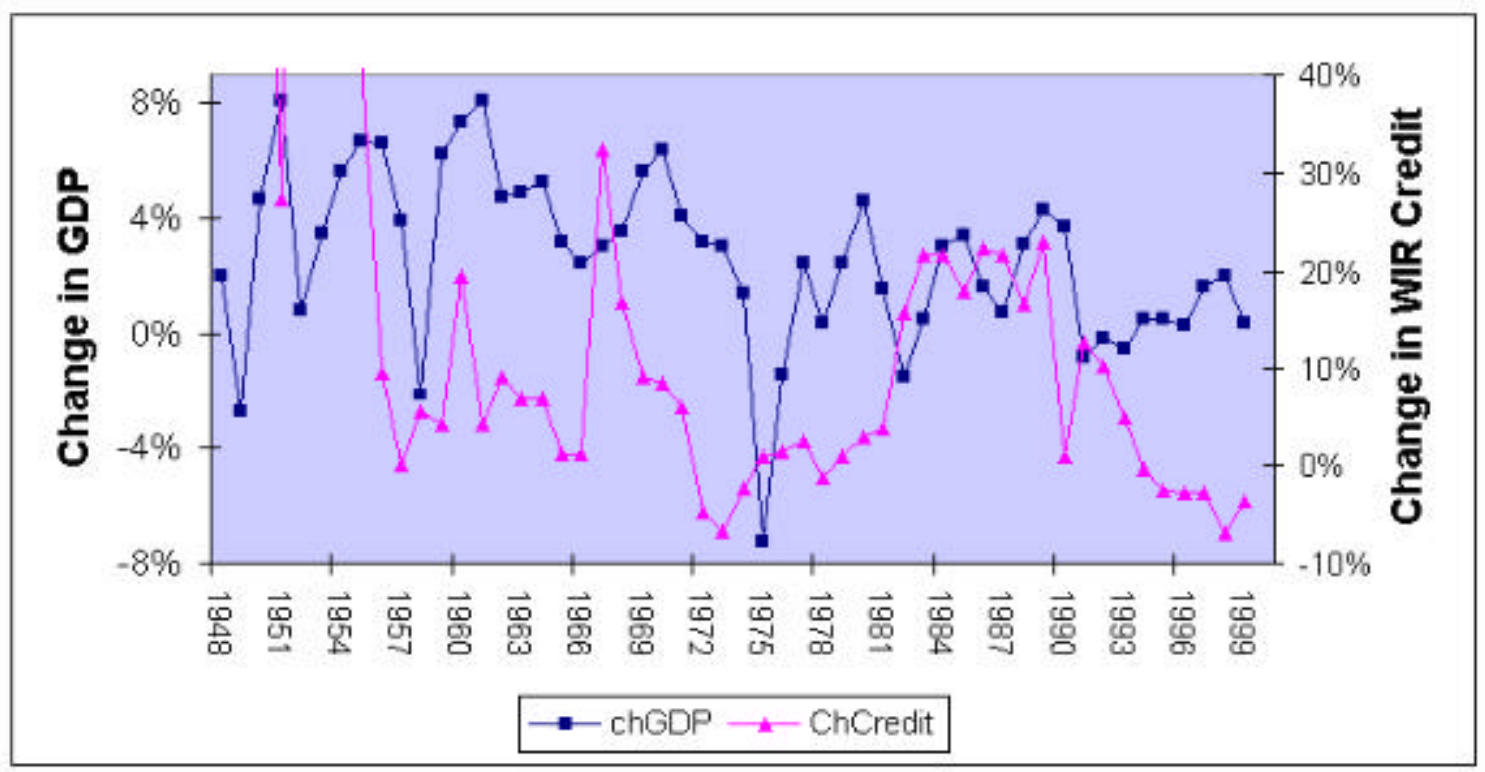

Figure 5: Change in Swiss GDP (left axis), and Change in Credits Advanced in WIR (right axis), both in 1990 Swiss Franks, 1948-99.

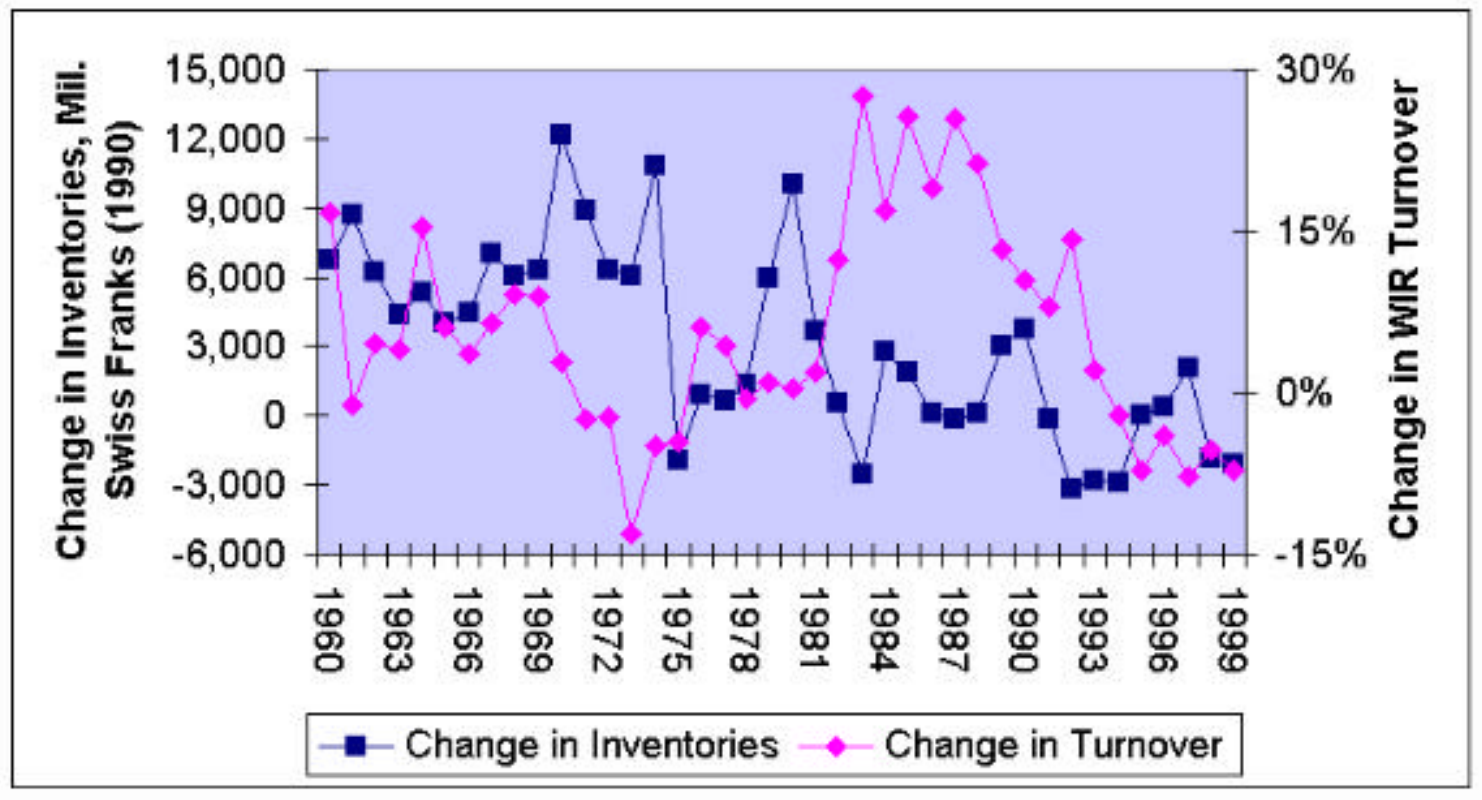

Figure 6: Change in Swiss Inventories, Millions of 1990 Swiss Franks (left axis), and Change in Annual Turnover in WIR (right axis), 1960-99. 


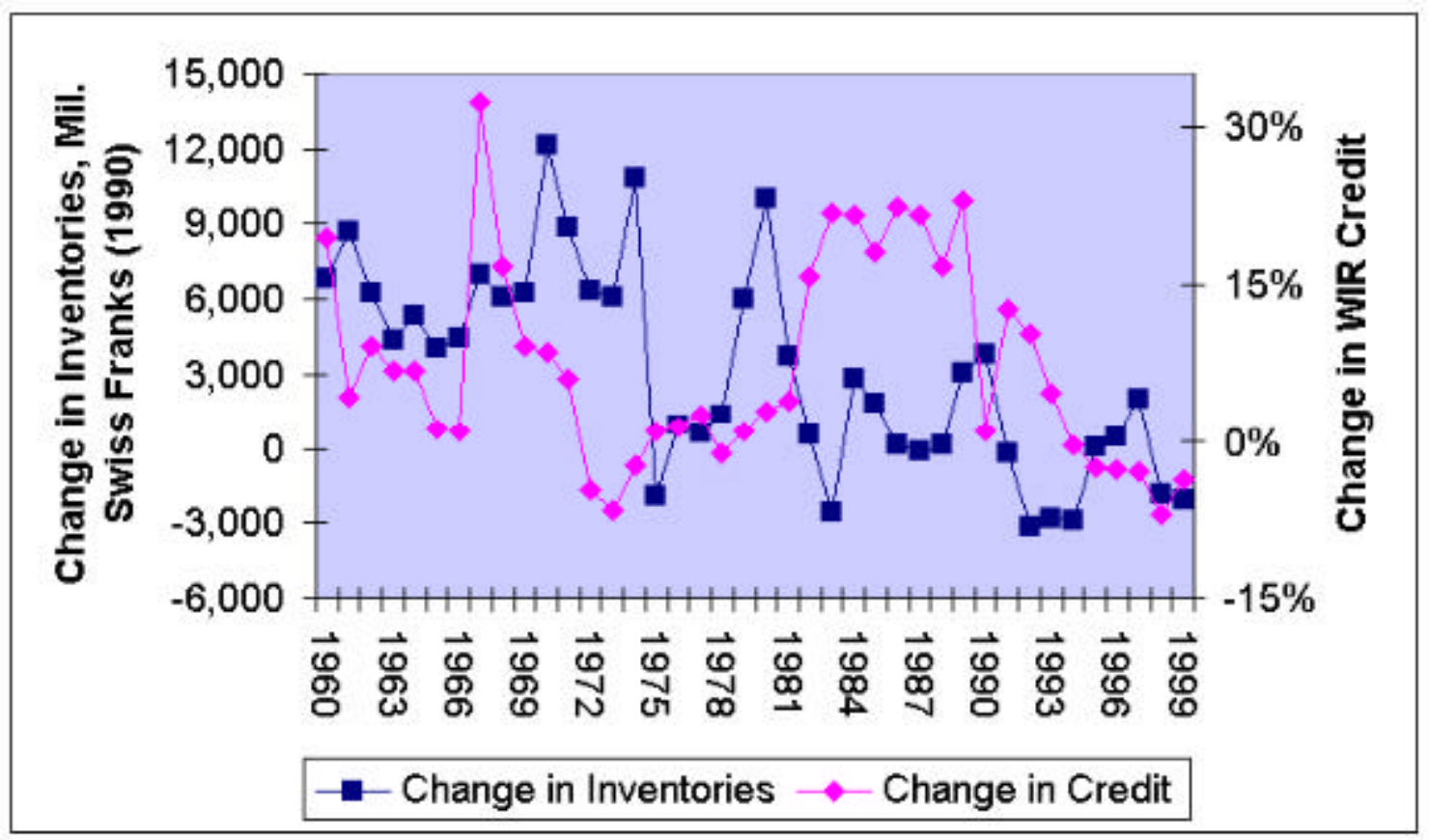

Figure 7: Change in Swiss Inventories, Millions of 1990 Swiss Franks (left axis), and Total Credits advanced in WIR (right axis), 1960-99.

In Table 4 below, Change in the number or WIR Participants is regressed against Change in Unemployment (in thousands, not as a percentage), Change in real GDP (in 1990 Swiss Franks), and Change in Real Inventories (also 1990 based.) The impression of an overwhelming correlation between membership and unemployment, seen in Figure 4 , is confirmed. R-squared terms are relatively low, however, and the Durbin-Watson term is in the indeterminate region, so the null hypothesis of first-order autocorrelation cannot be rejected at the $5 \%$ level.

Table 4: Participants in the WIR Barter Network, as Explained by Macroeconomic Variables 1960-1999

Dependent Variable: Change in Number of WIR Participants**

(t-stats in italics, ${ }^{*}: p$-value $\left.<0.05,{ }^{o}: p<0.10\right)$

\begin{tabular}{|l|r|r|r|}
\hline Equations & {$[1]$} & {$[2]$} & {$[3]^{* *}$} \\
\hline Variable & & & \\
\hline Constant & $\mathbf{1 3 8 1 . 4 6}$ & $\mathbf{1 3 6 8 . 1 3}$ & $\mathbf{- 9 . 0 1 1}$ \\
\hline Change Unemploy. & 1.299 & 1.291 & $-2.808^{*}$ \\
\hline & $\mathbf{1 9 . 2 9 9}$ & $\mathbf{2 0 . 2 8 0}$ & $\mathbf{0 . 0 2 4 2}$ \\
\hline & $3.130^{*}$ & $3.088^{*}$ & $1.485^{*}$ \\
\hline
\end{tabular}




\begin{tabular}{|c|c|c|c|}
\hline \multirow[t]{2}{*}{ Change GDP } & & 0.01251 & 1.892 \\
\hline & & 0.470 & $5.767 *$ \\
\hline \multirow[t]{2}{*}{ Change Inventories } & -0.0674 & -0.0824 & -0.363 \\
\hline & $-1.992 *$ & $-1.761^{\mathrm{o}}$ & $-2.272 *$ \\
\hline Regression Method & $A R 1$ & $A R 1$ & $A R 1$ \\
\hline R-squared & 0.279 & 0.283 & 0.963 \\
\hline Adj. R-squared & 0.240 & 0.223 & 0.960 \\
\hline Durbin-Watson Stat. & 1.344 & 1.37051 & 0.627 \\
\hline Rho (autocorrelation) & 0.9163 & 0.915 & 0.986 \\
\hline t-statistic of Rho & $16.691 *$ & $16.251 *$ & $63.098 *$ \\
\hline Log likelihood & -318.006 & -317.884 & 58.191 \\
\hline Number & 40 & 40 & 36 \\
\hline \multicolumn{2}{|c|}{$* *$ natural log of original, not } & \multicolumn{2}{|c|}{ change term, in [3] } \\
\hline
\end{tabular}

Sources: OECD: "Historical Statistics" (1998), "Economic Surveys: Switzerland" (1999); IMF: "Economic Outlook" (2000); Madison (1995); and Mitchell (1998).

In Table 5, annual Real Turnover in W/R, again in 1990 Swiss Franks, is regressed against the same variables as in Table 4 above. Note that Turnover is correlated with Unemployment, and thus counter-cyclical to this extent -- just as Membership was in the previous table. However, we now find a positive correlation with GDP, and a negative correlation with Inventories -- and thus a pro-cyclical relationship with these variables. Most coefficients are significant, but the low R-squared and Durbin-Watson terms do not inspire confidence.

In Table 6, I regress Credit against a slightly different set of variables, here using Change in Gross Capital (which includes inventories) rather than the change in inventories itself. With decreased value of existing capital stock in a recession, this emphasizes the counter-cyclical aspect even more. The regressions with high DurbinWatson statistics [1] and [2], show low R-squares, and those with high R-squares, the log forms [3] and [4], show low Durbin-Watsons.

Despite their plausible signs and significance of the coefficients, none of the regressions in Tables 4-6 are convincing, because of possible auto-correlation and low R-squared problems. In the final regressions, Table 7 below, these problems are partly resolved. 
Table 5: Total Turnover in the WIR Barter Network, as Explained by Macroeconomic Variables 1960-1999

Dependent Variable: Change in Annual Turnover of WIR-Bank

$\left(t\right.$-stats in italics, ${ }^{*}: p$-value $\left.<0.05,^{\circ}: p<0.10\right)$

\begin{tabular}{|c|c|c|c|c|}
\hline Equations & [1] & [2] & {$[3] * *$} & {$[4] * *$} \\
\hline \multicolumn{5}{|l|}{ Variable } \\
\hline \multirow[t]{2}{*}{ Constant } & 1381.46 & 1368.13 & -9.011 & -38.792 \\
\hline & 1.299 & 1.291 & $-2.808^{*}$ & $-5.077 *$ \\
\hline \multirow[t]{2}{*}{ Change Unemploy. } & 19.299 & 20.280 & 0.0242 & 0.1068 \\
\hline & $3.130 *$ & $3.088 *$ & $1.485^{*}$ & $2.677 *$ \\
\hline \multirow[t]{2}{*}{ Change GDP } & & 0.01251 & 1.892 & 3.594 \\
\hline & & 0.470 & $5.767 *$ & $5.752 *$ \\
\hline \multirow[t]{2}{*}{ Change Inventories } & -0.0674 & -0.0824 & -0.363 & \\
\hline & $-1.992 *$ & $-1.761^{\circ}$ & $-2.272 *$ & \\
\hline Regression Method & $A R 1$ & $A R 1$ & $A R 1$ & $A R 1$ \\
\hline R-squared & 0.279 & 0.283 & 0.963 & 0.0417 \\
\hline Adj. R-squared & 0.240 & 0.223 & 0.960 & $.261 \mathrm{E}-2$ \\
\hline Durbin-Watson Stat. & 1.344 & 1.37051 & 0.627 & 0.772 \\
\hline Rho (autocorrelation) & 0.9163 & 0.915 & 0.986 & 0.971 \\
\hline t-statistic of Rho & $16.691 *$ & $16.251 *$ & $63.098 *$ & $38.808 *$ \\
\hline Log likelihood & -318.006 & -317.884 & 58.191 & 13.034 \\
\hline Number & 40 & 40 & 36 & 52 \\
\hline \multicolumn{2}{|c|}{$* *$ natural log of original, not } & $\begin{array}{l}\text { "change" term, } \\
\text { used }\end{array}$ & in & [3], [4]. \\
\hline
\end{tabular}

Sources: Same as Table 4. 
Table 6:Credit Advanced in the WIR Barter Network, as Explained by Macroeconomic Variables 1960-1999

Dependent Variable: Change in Annual Credit Advanced by WIR-Bank $\left(t\right.$-stats in italics, ${ }^{*}: p$-value $\left.<0.05,{ }^{\circ}: p<0.10\right)$

\begin{tabular}{|c|c|c|c|c|}
\hline$\underline{\text { Equations }}$ & [1] & [2] & {$[3]^{* *}$} & {$[4]^{* *}$} \\
\hline \multicolumn{5}{|l|}{ Variable } \\
\hline \multirow[t]{2}{*}{ Constant } & 11.034 & 10.172 & -1.112 & --25.554 \\
\hline & 1.186 & 1.17157 & -0.336 & $-4.578 *$ \\
\hline \multirow[t]{2}{*}{ Change Unemploy. } & 0.433 & 0.455 & 0.0692 & 0.0538 \\
\hline & $2.154 *$ & $2.373 *$ & $1.864^{\circ}$ & $1.697^{\circ}$ \\
\hline \multirow[t]{2}{*}{ Change GDP } & -0.207 & & & 2.6536 \\
\hline & -0.370 & & & $4.488^{*}$ \\
\hline \multirow[t]{2}{*}{ Change Gross Cap. } & & & 0.5734 & -0.179 \\
\hline & & & $2.024 *$ & -0.566 \\
\hline Regression Method & $A R 1$ & $A R I$ & $A R 1$ & $A R I$ \\
\hline R-squared & 0.103 & 0.101 & 0.281 & 0.690 \\
\hline Adj. R-squared & 0.0662 & 0.0829 & 0.237 & 0.661 \\
\hline Durbin-Watson Stat. & $2.490 *$ & $2.497 *$ & 0.592 & 0.818 \\
\hline Rho (autocorrelation) & 0.6967 & 0.689 & 0.994 & 0.964 \\
\hline t-statistic of Rho & $6.902^{*}$ & 6.82298 & 116.617 & $30.564 *$ \\
\hline Log likelihood & -224.595 & -224.665 & 27.130 & 34.412 \\
\hline Number & 51 & 51 & 36 & 36 \\
\hline \multicolumn{2}{|c|}{ ** natural log of original, not } & $\begin{array}{l}\text { "change" term, } \\
\text { used }\end{array}$ & in & [3], [4]. \\
\hline
\end{tabular}

Sources: Same as Table 4.

In Table 7, I use the ratio of Credit over total barter Turnover. In contrast to the results of Table 4, the regressions on number of WIR participants, I find that the Unemployment term is now not significant. The "Change in Inventories and Change in GDP, are highly significant in regression [2]. The Durbin-Watson statistic for this equation, however, 
indicates that the null hypothesis of first-order autocorrelation cannot be rejected at five percent.

Since the previous regressions show Credit as correlated with Inventories, while Turnover volume is correlated with GDP, the ratio of Credit to Turnover in Table 7, therefore, correlates with Inventories and against GDP. As in the IRTA regressions of Table 3, however, collinearity is evident between the GDP and Inventory terms. In both cases some functional relationship is likely, although it is not specified here.

\section{Table 7: WIR Credit-Turnover Ratio, as Explained by Macroeconomic Variables 1948-1999}

Dependent Variable: Annual Ratio of Credit to Turnover,

$\left(t\right.$-stats in italics, ${ }^{*}: p$-value $\left.<0.05,{ }^{\circ}: p<0.10\right)$

\begin{tabular}{|c|c|c|c|c|}
\hline Equations & [1] & [2] & [3] & [4] \\
\hline \multicolumn{5}{|l|}{ Variable } \\
\hline \multirow[t]{2}{*}{ Constant } & $1.86 \mathrm{E}-01$ & 1.89E-01 & $1.92 \mathrm{E}-01$ & 2.45E-01 \\
\hline & $5.314 *$ & $5.448 *$ & $5.067 *$ & $11.192 *$ \\
\hline \multirow[t]{2}{*}{ Time } & $4.66 \mathrm{E}-03$ & $4.49 \mathrm{E}-03$ & $4.34 \mathrm{E}-03$ & 3.04E-03 \\
\hline & $4.402 *$ & $4.648 *$ & $4.123 *$ & $4.400 *$ \\
\hline \multirow[t]{2}{*}{ Unemploy. } & $-5.50 \mathrm{E}-05$ & & & \\
\hline & -0.384 & & & \\
\hline \multirow[t]{2}{*}{ Change GDP } & $-1.53 E-06$ & $-1.52 \mathrm{E}-06$ & & $-8.73 E-07$ \\
\hline & $-2.633 *$ & $-2.659 *$ & & $-1.767^{\circ}$ \\
\hline \multirow[t]{2}{*}{ Chnge Invnt. } & 2.23E-06 & 2.23E-06 & 3.63E-07 & \\
\hline & $2.089 *$ & $2.129 *$ & 0.434 & \\
\hline Regress.Mthd & $A R 1$ & $A R 1$ & $A R 1$ & AR1 \\
\hline R-squared & 0.457 & 0.419 & 0.343 & 0.568 \\
\hline Adj.R-squrd & 0.394 & 0.396 & 0.307 & 0.550 \\
\hline Durb.-Watson & $2.069 *$ & 1.664 & $2.229 *$ & $2.413^{*}$ \\
\hline Rho & 0.832 & 0.983 & 0.846 & 0.788 \\
\hline t-stat. of Rho & $9.788^{*}$ & $65.533^{*}$ & $10.709 *$ & $9.057 *$ \\
\hline Log liklhood & -111.74 & -416.85 & -108.08 & -132.53 \\
\hline
\end{tabular}




\begin{tabular}{|l|l|l|l|r|r|}
\hline Number & 40 & 40 & 40 & 52 \\
\hline
\end{tabular}

Sources: Same as Table 4.

\section{Conclusions and Implications}

The Swiss results are less persuasive than the US, perhaps due to the poorer coverage of its national data (Maddison 1995, p. 135) -- as opposed to its barter exchange data. Nevertheless, there is substantial evidence for the general form of our hypothesis, that centralized barter exchange is counter-cyclical.

There remains the vital question, however, as to why this counter-cyclicity occurs. A basic difference of opinion exists within macroeconomic theory as to whether instability is more due to price rigidity, or to inappropriate levels of money and credit. Keynes (1936) recognized that both conditions can and do apply, and that either can lead to instability.

The reigning macroeconomic consensus, as represented by Mankiw (1993), puts the blame more on rigid prices; economists like Colander (1996) stress monetary and credit conditions. Reflecting the consensus around the "sticky price" school of macroeconomics, most commentary on the impact of e-commerce has concentrated on prices, as we have seen. But if a barter exchange's members charge prices that do not diverge significantly from its cash prices -- those charged to their non-members -- then counter-cyclicity may derive from barter's ability to create credit.

The two barter exchanges studied here have very different pricing practices. The North American IRTA is likely to benefit its participants through greater price flexibility, and even under-the-table "discounts" off the list price (Magenheim and Murrell 1988). The Swiss WIR, by contrast, is unlikely to engage in pricing that differs substantially from cash deals. WIR credits cannot be exchanged for cash at a discount, a decision historian Defila (1994) sees as crucial for the organization.

The IRTA is a loose affiliation of "barter middle-men," not a nationally centralized exchange like the WIR-bank. The totality of the US barter exchanges is far smaller than WIR, both absolutely and relative to the national economy. IRTA activities are less public and less centralized, and therefore, far less subject to the scrutiny of other customers.

Prices available to members of the WIR, by contrast, are usually matters of public information. Lower prices on barter than cash would surely divert trade to the former. This is undesirable for most businesses. Within a cash-wide economy, other things being equal, cash is always preferred (Healey 1996).

The possibility remains that barter may have forced greater flexibility in network members' cash prices. But since WIR's bylaws restrict membership to small and medium businesses (Defila 1994), members will usually have had little price-setting power. Thus, the counter-cyclical history of WIR is likely more due to its credit creation than to added price flexibility. Inventory flexibility, however, could also be a factor, even before widescale use of computers. The IRTA's counter-cyclical path probably derives from all three causes, with effects more closely balanced. 
Whatever the causes, if these network exchanges are indeed counter-cyclical, this is not the case for all "network economies". Telecommunications networks are highly subject to increasing returns to scale, unlike older industries -- and standard neoclassical theory (Romer 1997, Howitt and Phillipe 1998). Such industries are likely to fuel faster growth, but also, as their importance to the economy increases, greater macroeconomic instability.

Networks like those studied here also have increasing returns and "network externalities," yet appear to be counter-cyclical. Although started long before the internet, these networks offer important historical evidence on the macroeconomics of barter.

It is not too soon to begin studying this evidence. To quote Mervyn King, Deputy Governor of the Bank of England, the logic of electronic barter may imply that "central banks in their present form would no longer exist; nor would money.... The successors to Bill Gates could put the successors to Alan Greenspan out of business." (King 1999)

\section{References}

AGHION, Philippe, and Peter Howitt (1998) Endogenous Growth Theory, Cambridge: MIT.

ANDERS, George (2000) "First E-Shopping, Now E-Swapping" Wall St. Journal, New York; Jan.17.

BEATTIE, Alan (1999) "Internet Heralds Coincidence of wants," Financial Times, Dec. 6.

COLANDER, David (1996), ed., Beyond Micro-foundations: Post Walrasian

Macroeconomics. Cambridge, UK: Cambridge University Press.

DEFILA, Heidi (1994) "Sixty Years of the WIR Economic Circle Cooperative: Origins and Ideology of the Wirtschaftsring," WIR Magazin, September. An English translation by Thomas Geco is available at http://www.ex.ac.uk/ RDavies/arian/wir.html.

Economic Report of the President (1996), Washington, DC: US Government Printing Office.

Economist Magazine (2000a), "Economics Focus: Who Needs Money?" January 22.

Economist Magazine (2000b), "Economics Focus: E-Money Revisited," July 22.

FRIEDMAN, Benjamin (1999) "The Future of Monetary Policy", International Finance, December.

GREENSPAN, Alan (1999) "Testimony before the Joint Economic Committee," US Congress, June 14. 
HEALEY, Nigel (1996) AWhy is Corporate Barter?@ Business Economics, April, Vol. 31 , no. 2.

KING, Mervyn (1999) "Challenges for Monetary Policy: New and Old." Paper prepared for the Symposium on "New Challenges for Monetary Policy" sponsored by the Federal Reserve Bank of Kansas City at Jackson Hole, Wyoming, 27 August 1999.

http://www.bankofengland.co.uk/speeches/speech51.pdf .

IRTA (1995), AFact Sheet: Why Business People Barter.@

ww2.dgsys.com/ irta/fswhybpp.html, Falls Church, Virginia: IRTA.

KEYNES, John Maynard (1936) The General Theory of Employment, Interest, and Money. New York: Harcourt Brace Jovanovich, 1964.

MADISON, Angus (1995) Monitoring the World Economy, 1820-1992, Paris: OECD.

MAGENHEIM, E. and P. Murrell (1988) "How to Haggle and Stay Firm: Barter as Hidden Price Discrimination" Economic Inquiry, July, Vol. 26, no.3.

MANKIW, N. (1993) editor of ASymposium on Keynesian Economic Theory Today,@ Journal of Economic Perspectives, Vol. 7, no. 1.

MIEIERHOFER, L. (1984) Volkswirtsaftliche Analyse des WIR-Wirtschaftsrings, WIR: Basel, Switzerland.

MITCHELL, B.R. (1998) International Historical Statistics, Europe, 1750-1993, UK: MacMillan.

OECD (2000) Economic Outlook, Jan., Paris: OECD.

(1999) Economic Surveys: Switzerland, Paris: OECD.

(1998) Main Economic Indicators, Historical Statistics, 1960-97 [computer file], Paris: OECD.

POLANYI, Karl (1947) The Great Transformation: the political and economic origins of our time, Boston: Beacon Press, 1957.

ROMER, Paul (1986) "Increasing Returns and Long-Run Growth," Journal of Political Economy Vol. 94, no. 5 (October): pp. 1002-37.

STODDER, James (1998) "Corporate Barter and Macroeconomic Stabilization," International Journal of Community Currency Research, Vol.2, no.2, http://www.geog.le.ac.uk/ijccr/volume2/2js.htm.

(1995) AThe Evolution of Complexity in Primitive Economies: Theory," and "...Empirical Evidence," Journal of Comparative Economics, Vol. 20: no 1., February and no. 2, May. 
STUDER, Tobias (1998) WIR in Unserer Volkwirtschaft, Basel: WIR.

STUTZ, Emil (1984) "Le Cercle Économique-Societé Coopéreative WIR - Une Retrospective Historique," Basle: WIR.

WIR (2000) E-mail statistics from Public Relations, March and April.

WENNINGER, John (1999) "Business-to-Business Electronic Commerce," Current Issues in Economics and Finance, June, Volume 5, no. 10.

WORLD BANK (2000) "Future of Monetary Policy and Banking Conference: A Conference Looking Ahead to the Next Twenty-Five Years," July 11, 2000, World Bank,Washington, D.C.

http://www.worldbank.org/research/interest/confs/upcoming/papersjuly11/papjuly11.htm .

Last Updated: Wednesday, April 032002 12:00

Rensselaer at Hartford, 275 Windsor St, Hartford, CT 06120

For more information: 1-800-433-4723 or info@rh.edu 